\title{
Changes in innate and adaptive immune response to Lagovirus europaeus Gl.1 (Rabbit Haemorrhagic Disease Virus -RHDV) infection
}

\author{
BEATA HUKOWSKA-SZEMATOWICZ
}

Institute of Biology, University of Szczecin, Wąska 13, 71-412 Szczecin, Poland

Molecular Biology and Biotechnology Center, University of Szczecin, Wąska 13, 71-412 Szczecin, Poland, ORCID: 0000-0002-27762799

Corresponding author

e-mail: beata.hukowska-szematowicz@usz.edu.pl

Keywords neutrophil, lymphocytes, viral infection, rabbits, rabbit haemorrhagic disease virus

Abstract Lagovirus europaeus GI.1 (Rabbit Haemorrhagic Disease Virus - RHDV) is a virus that causes rabbit haemorrhagic disease (RHD) that affects domestic and wild rabbits worldwide. Due to the fact that the impact of RHDV on the host organism, and more precisely, its influence on the immune system, is crucial for the spread of this infection in rabbits, it is very important to understand the role of the immune system components in the course of infection with this virus. The aim of the study was to present innate and adaptive immune response to three strains (V411, 1092V, Wika) of the Lagovirus europaeus GI.1 (RHDV) identified at different times. Twelve indices were examined for the innate immune response and nine for the adaptive response. The results indicate that PMN cells (polymorphonuclear cells, neutrophils) play an important role in the response to this infection and give new insights into the function of $\mathrm{CD} 4^{+}$ Th and CD8 ${ }^{+}$Tc lymphocytes. The most immunogenic was the Wika strain from 1996.

\section{Zmiany we wrodzona i nabytej odpowiedź immunologicznej po zakażeniu Lagovirus europaeus GI.1 (Rabbit Haemorrhagic Disease Virus - RHDV)}

Słowa kluczowe neutrofil, limfocyty, infekcja wirusowa, królik, wirus krwotocznej choroby królików

Streszczenie Lagovirus europaeus GI.1 (Rabbit Haemorrhagic Disease Virus - RHDV) infekuje króliki domowe i dzikie na całym świecie, wywołując u nich krwotoczną chorobę królików (RHD-rabbit haemorrhagic disese). Z uwagi na fakt, że wpływ RHDV na organizm żywiciela, a dokładniej jego wpływ na układ odpornościowy, ma kluczowe znaczenie dla rozprzestrzeniania się tej infekcji u królików, bardzo ważne jest poznanie roli elementów układu odpornościowego w przebiegu zakażenia tym wirusem. Dlatego też celem badań było przedstawienie zmian we wrodzonej i nabytej odpowiedzi immunologicznej po zakażeniu trzema szczepami (V411, 1092V, Wika) Lagovirus europaeus GI.1 (RHDV), zidentyfikowanymi w różnym czasie. W zakresie wrodzonej odpowiedzi immunologicznej zbadano dwanaście wskaźników, a w nabytej dziewięć. Uzyskane rezultaty wskazują na udział komórek PMN (polimorfonuklearnych, neutrofilii) jako ważnych elementów w odpowiedzi na to zakażenie oraz rzucają nowe spojrzenie 
na udział limfocytów $\mathrm{CD}^{+}{ }^{+} \mathrm{Th}$ i $\mathrm{CD} 8^{+} \mathrm{Tc}$. Najbardziej immunogenny okazał się szczepem Wika z 1996 r.

\section{Introduction}

The protection of the host against infection is ensured by well-functioning innate and adaptive immunity and increased host tolerance to infection (Iwasaki, Pillai, 2014). Recently, intensive research has been undertaken in Lagomorphs (rabbits, hares, etc.) to learn about the immune system in terms of its defensive reactions to pathogenic factors, especially viruses causing acute diseases (Esteves et al., 2018; Neves et al., 2015; Pinheiro et al., 2016). This is associated with the fact that the rabbit is one of the most frequently used animal laboratory models for immunological tests, including tests for viral and bacterial infections but also for other pathological conditions (Esteves et al., 2018; Neves et al., 2015).

Lagovirus europaeus GI.1 (Rabbit Haemorrhagic Disease Virus - RHDV) (Le Pendu et al., 2017) causing rabbit haemorrhagic disease (RHD) was first reported in 1984 in China in rabbits imported from Germany (Liu et al., 1984). Since the identification of RHDV more than 30 years ago, researchers have discovered its new variants GI.1a (G6/RHDVa) (in 1996) (Capucci et al., 1998) and new genotypes - GI.2 (RHDV2/b) (in 2010) (Le Gall-Recule, Zwingelstein, 2011). The impact of RHDV on the host organism, and more specifically, its effect on the immune system (Holmes, Grenfell, 2009), are key for the spread of this infection in rabbits (Figure 1).

That is why it is so important to understand the role of the immune system components in the course of infection with RHDV. Studies conducted in Poland (Hukowska-Szematowicz, 2013; Hukowska-Szematowicz, Deptuła, 2008; Hukowska-Szematowicz, Deptuła, 2011; NiedźwiedzkaRystwej, 2013; Niedźwiedzka-Rystwej, Deptuła, 2010; Tokarz-Deptuła, 2009; Trzeciak-Ryczek, Tokarz-Deptuła, Deptuła, 2016; Trzeciak-Ryczek, Tokarz-Deptuła, Deptuła, 2017) and other centres (Huang, 1991; Marques et al., 2012; Semerjyan et al., 2019; Teixeira et al., 2012) have shown that numerous elements of the immune system, such as macrophages, T and B lymphocytes in the liver, spleen and lymph nodes as well as peripheral blood leukocytes and their products play a large role in the infection of Lagovirus europaeus GI.1 (RHDV) and course of RHD.

Therefore, the aim of this study was to present the changes in the host's innate and adaptive immune response to the infection with three strains of Lagovirus europaeus GI.1 (RHDV): Hungarian 1092V, Austrian V411 and German-Wika. The strains origin from the first years of diseases apperance in Europe 1988 (1092V), 1989 (V411) and 1996 (Wika). At this work has been analyzed twelve parameters of innate immune response (adherence capacity of polimorfonuclear cells-PMN cells, neutrophils); absorption capacity of PMN cells- absorption index and percent of absorbing cells; nitroblue tetrazolium (NBT) reduction tests - spectrophotometric, spontangeous, stimulated and index of stimulation (IS); metabolic activity coefficient of PMN cells (WAMG) - spontaneous and stimulated; myeloperoxidase (MPO) activity and lysozyme (LZM) concentration and activity) and seven parameters of adaptive immune response (percent of CD5 $5^{+}$ $\mathrm{T}$ lymphocytes, percent of CD $4^{+} \mathrm{Th}$ lymphocytes, $\%$ of $\mathrm{CD} 8^{+} \mathrm{Tc}$ lymphocytes, percent of CD25 lymphocytes, percent of CD19+ B lymphocytes, and IgG serum amount, total Ig concentration). 


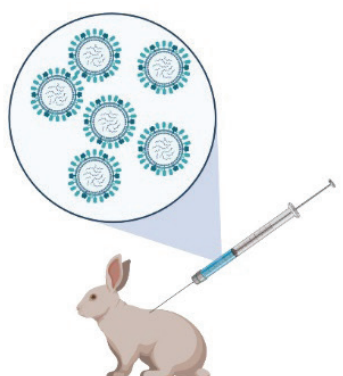

Resistant host *

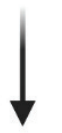

Elimination of RHDV

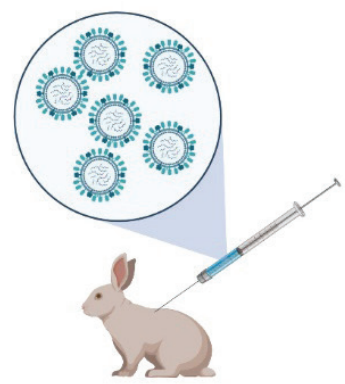

Tolerant host

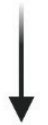

Reduction of tissue damage

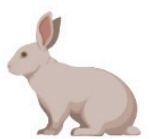

Host alive

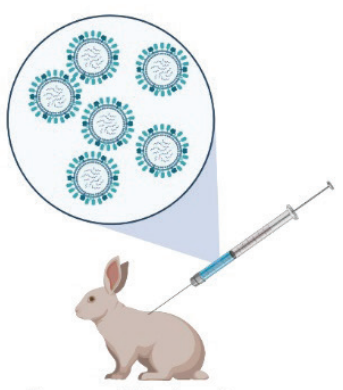

Susceptible host

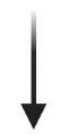

No elimination of

RHDV

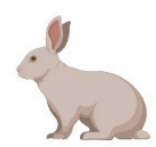

Host alive

*only young rabbits infected with RHDV

A resistant host regains physical fitness by recognizing and eliminating the pathogen (animals less than two months old do not show symptoms of RHD, infection does not lead to their death). A tolerant host recovers from infection through the effectiveness and integrity of the mechanisms of innate and adaptive immunity, which reduces tissue damage. A susceptible host recognizes the pathogen but is unable to eliminate the virus through its immune mechanisms, which leads to death.

Figure 1. Host strategies in RHDV infection

\section{Materials and Methods}

\section{Animals}

The studies were performer on 45 mixed-breed rabbits of both sex, about weight 2.5-4.5 $\mathrm{kg}$. Marked as conventional animals (Annon, 1987), from a utility farm conducted under comlete zoo-technical and veterinary supervision. The animals did not present any symptoms pointing to a disease, were not subjected to any vaccination, and did not feature anti-RHDV antibodies in serum. During the study, the rabbits remained at the vivarium of the University of Szczecin, 
where the conditions of the rooms in the aspect of temperature, humidity and lighting conformed to national standards (Annon, 2006). In the room, apart from natural lighting, there was also artificial lighting- glow discharge tubes. Animals were fed with full-portion rabbit feed LSK, manufactured in Miłosławiec near Poznań, in the quantity of $0.15-0.20 \mathrm{~kg} / \mathrm{day}$ and had at libitum access to water.

\section{Lagovirus europaeus GI.1 (RHDV)}

Three European RHDV strains, differing in their identification times, were used to infect the animals. Strain 1092V from Hungary - 1988, V411 from Austria - 1989, and Wika from Germany - 1996. The presence and titre of the virus used for the experiment were defined with haemagglutination reaction (HA), using erythrocytes of human 0 group $(\mathrm{Rh}+)$, and immunoenzymatic test ELISA. The titer in the HA reaction for the studied strains RHDV was respectively: 1,280, $2,560,10,240$. The pathogenicity of all strains up to 48 hours of the study was $100 \%$. RHDV strains were administered to the rabbits intramuscularly (leg muscles) in the form of suspension in $1 \mathrm{ml}$ of glycerol. In turn, control animals were administered with placebo- $1 \mathrm{ml}$ of glycerol. Each of the RHDV strains used for infecting rabbits came from the naturally dead animals. The strains in the form of liver homogenisate, were used for experimental infection of rabbits from whom after death liver was sampled, which was then used for infection of animals studied, by administering the liver tissue to them in the form of $20 \%$ homogenisate cleared by centrifugation at 3,000 rpm, 10\% chloroforming for 60 minutes and centrifugation again, and then suspension in glycerol in the 1:1 proportion (Niedźwiedzka-Rystwej, Deptuła, 2010). All the antigens of RHDV prepared had the same number of molecules determined with floating density in caesium chloride of $1.31-1.34 \mathrm{~g} / \mathrm{dm}^{3}$.

\section{The scheme of the experiment}

The animals designed for infection were divided into three groups of ten animals, who were administered intramuscularly (lower limb muscles) RHDV suspended in $1 \mathrm{ml}$ of glycerol (group 1 - 1092V strain, group 2 - V411, group 3 - Wika). Rabbits of control groups - three group of five animals each analogically received $1 \mathrm{ml}$ of glycerol. Blood for immunological studies was drawn through a port from the marginal vein of the ear onto an anti-coagulant or without it, depending on the needs and requirements of the method applied in the study. For all groups of the studied experimental animals, blood was drawn at hour "0", namely before the administration of the RHDV in the group of infected rabbits and glycerol in the group of control animals, and then at hours $8,12,24,36$. All animals died to 48 hours of the experiment. In animals infected with the RHDV, at particular hours of the study, clinical symptoms were recorded by observation of animals and mortality was recorded (on the basis of which the mortality index was calculated). Before commencement of the experiment, all rabbits were subjected to the test for presence of anti-RHD antibodies using ELISA test. During the experiment, zoo-hygienic parameters were controlled every 24 hours, and the reading was always done at 8.00 AM.

\section{Indices of innate and adaptive immune response}

Adherence capacity of PMN cells in peripheral blood was determined with Lorente et al. (1973) method. The PMN cells' absorption capacity of the model strain of Staphylococcus aureus bacteria, strain 209P, was marked with Brzuchowska and Ładosz method, as modified by Deptuła 
(1991), Zeman (1995) and Hukowska (2000). The capacity for reduction of the NBT was determined with cytochemical method in a spontaneous and stimulated test and with spectrophotometric method (Park, Fihring, Smithowich, 1968; Raman \& Poland, 1975). Also, metabolic activity coefficient of neutrophilic granulocytes (WAMG) was marked acc. to Grządzielska (1976), as well as stimulation index (IS) acc. to Lechowski et al. (1991). MPO activity in PMN cells was assessed according to the Graham method described by Zawistowski (1976) and Afanasyev and Kolot (1971). In turn, the LZM concentration and activity in serum was determined by the method of plate diffusion according to Hankiewicz \& Świerczek (1975) and Szmigielski (1972). Marking of the percentage of T, Th, Tc cells and lymphocytes with $\mathrm{CD} 25^{+}$receptor was done according to the method described by Deptuła et al. (1998). It involved monoclonal antibodies (mouse anti-rabbit) (Serotec, USA) to identify $\mathrm{CD}^{+}$( $\mathrm{T}$ cells), $\mathrm{CD}^{+}$(Th cells), $\mathrm{CD}^{+}$(Tc cells), lymphocytes with receptor $\mathrm{CD} 25^{+}$and $\mathrm{CD} 19^{+}$(B cells). The marked cells were measured at the flow cytometer FACScan by Becton Dickinson (USA) with FACSDiva software. Marking of total number of immunoglobulins in serum was done using McEwan (1970) method. Serum IgG immunoglobulin was marked with platelet method according to the IgG standards (ICN), according to the manufacturer's protocol.

\section{Statistical Analysis}

Data are presented as mean \pm standard deviation (SD). All statistical analyses were performed using StatView-5 Software (SAS Institute, Cary, NC, US). Between-group differences (infected rabbits and non-infected rabbits-control) evaluated using non-parametric tests (Mann-Whitney U or Kruskal-Wallis) or analysis of variance (ANOVA) with Fisher's PLSD. A p-value $\leq 0.05$ was considered to indicate statisticallly significant.

\section{Results}

\section{Changes in the innate immune response to Lagovirus europaeus GI.1 (RHDV) infection}

At this work, analyzed the changes of innate and adaptive immune response, evoked by three strains - 1092V, V411 and Wika during infections and compared these findings with the levels obtained in non-infected rabbits (control). Despite the fact, that during the experimrnt, blood samples were collected from animals in a dynamic (temporal) system, the results of the researches were presented in a static form (not taking into account time), due to the fact that there are limited data on this subject. The research presented the next step in understanding the role of the immune system components in the course of RHDV infection.

The adherence capacity of PMN cells (Figure 2A) has been elevated during Wika strain infections (1.4-fold, $\mathrm{p}<0.05)$. After V411 and 1092V strains infection, the adherence of capacity was comparable to controls. Moreover, infection with all three strains has been different in absorption capacity of PMN cells (Figure 2B,C). The analysis showed elevated values of absorption index (Figure 2B) after Wika strain infection (1.1-fold, $\mathrm{p}<0.05)$, and decreased after V411 (16\% reduction, $\mathrm{p}<0.05)$ and $1092 \mathrm{~V}(6 \%$ reduction, $\mathrm{p}<0.05)$. However, the percentage $(\%)$ of absorbing cells (Figure 2C) after Wika antigen infection has been comparable to controls $(\mathrm{p}=0.3)$. In regard to this analysis, a reduction has been observed after V411 (7\% reduction, $\mathrm{p}<0.05)$ and $1092 \mathrm{~V}$ 
( $4 \%$ reduction, $\mathrm{p}<0.05$ ) infection strains. From all performed NBT reduction tests (Figure $2 \mathrm{D}-\mathrm{F})$, only the stimulated NBT analysis showed increased values for Wika strains $(1.2$-fold, $\mathrm{p}<0.05)$. For all other analyzes strains, do not indicated any statistical changes. A change was also recorded in the case of the stimulation index (Figure $2 \mathrm{G}$ ), but only in the case of V411 strain infection $(1.0$-fold, $\mathrm{p}<0.05)$.
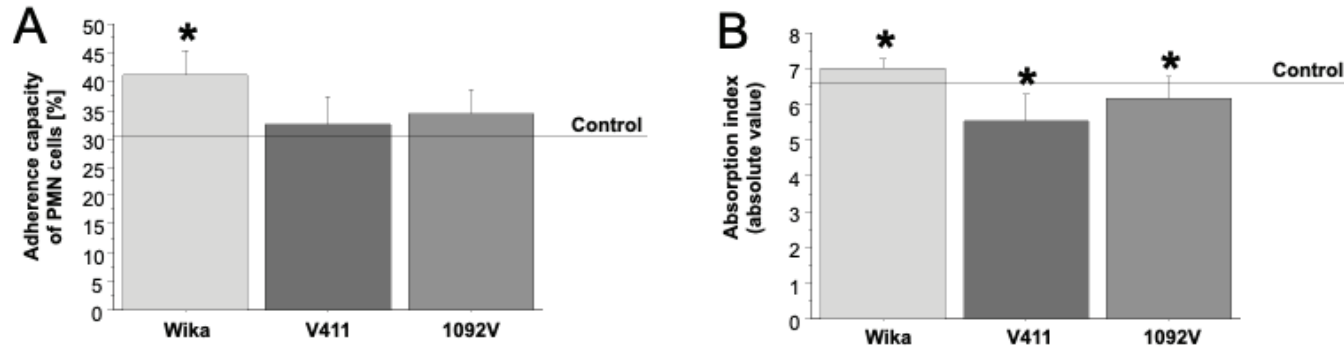

C

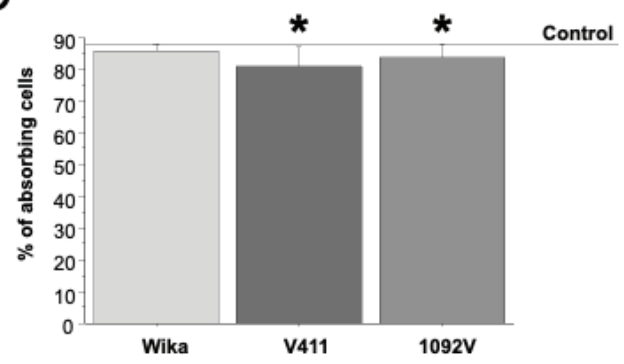

E
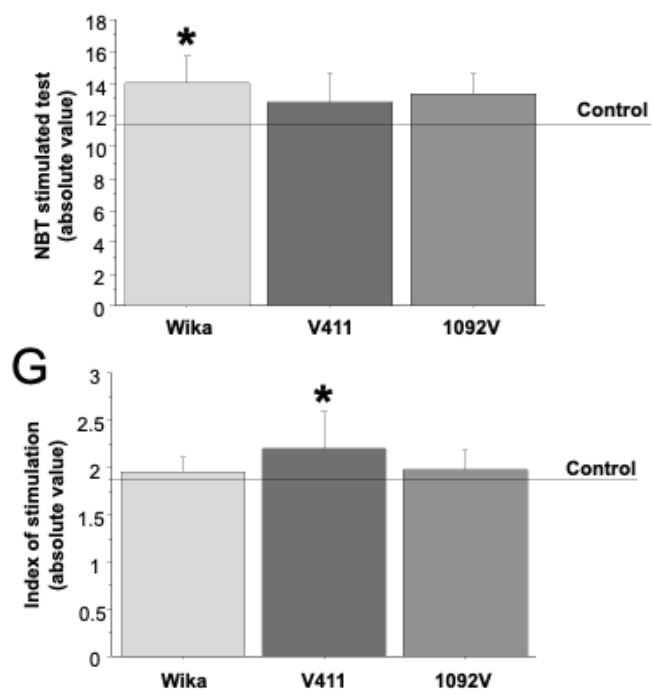

D

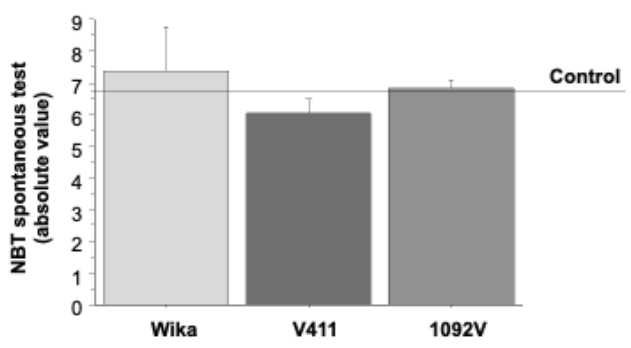

$\mathrm{F}$
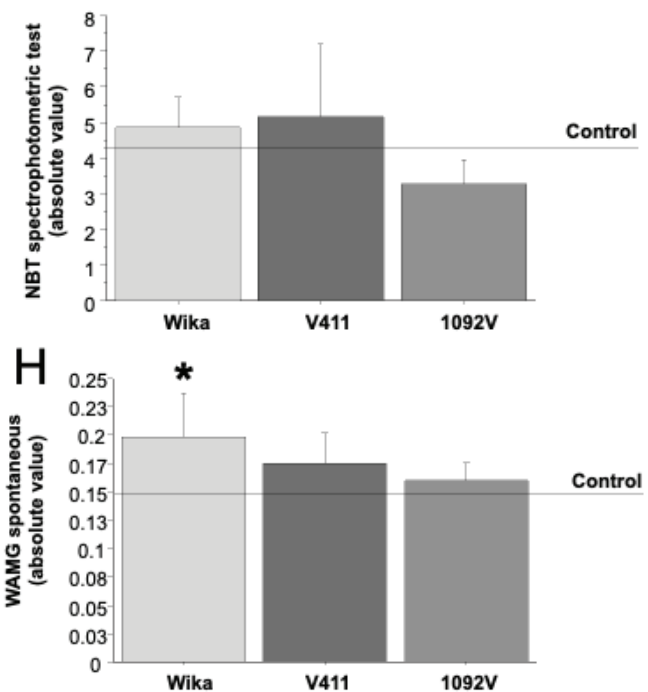

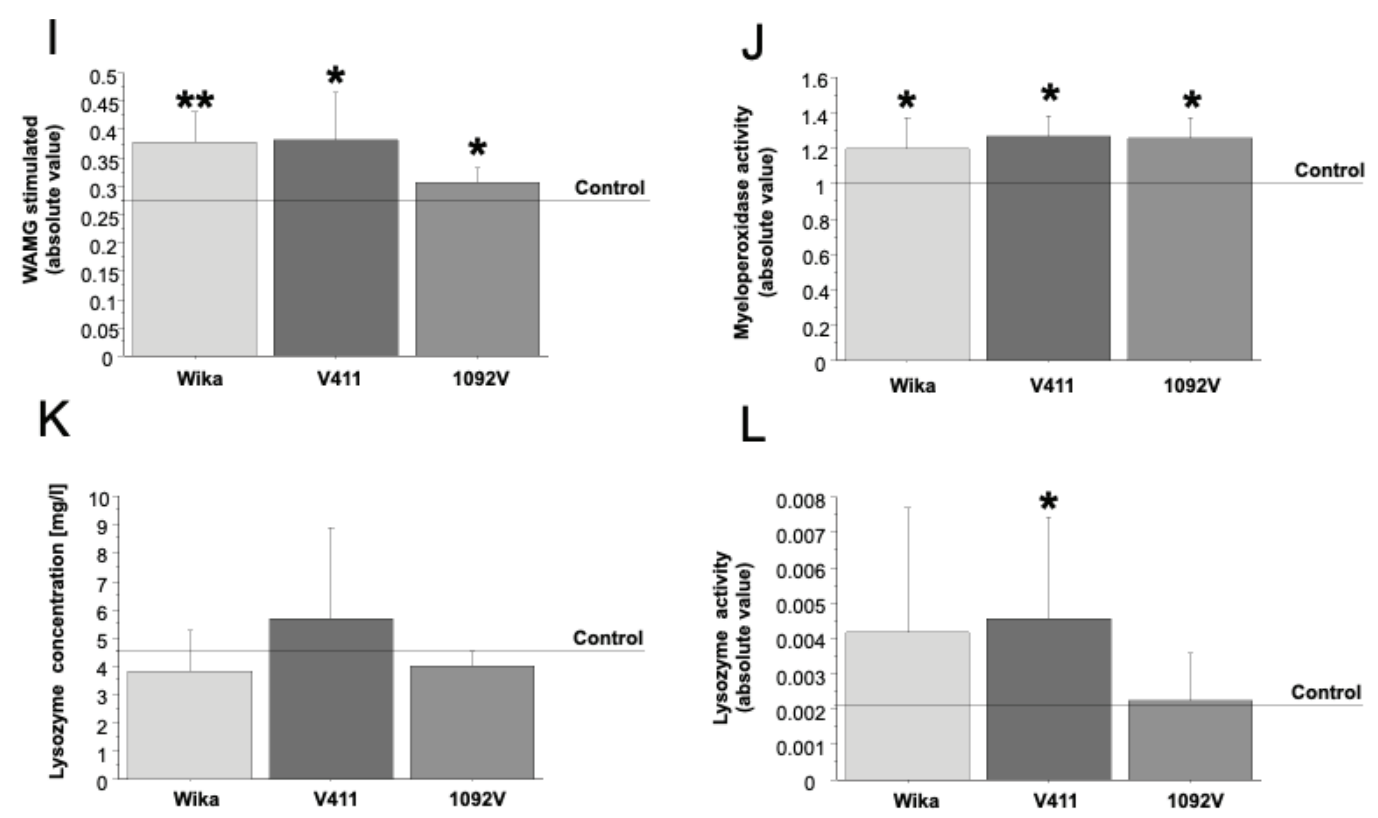

$* \mathrm{p}<0.05 ;{ }^{* *} \mathrm{p} \leq 0.0001$. A. Adherence capacity of PMN cells; B. Absorbsion index; C. Percent of absorbing cells; D. NBT spontaeeous test; E. NBT stimulated test; F. NBT spectrophotometric test; G. Index of stimulation; H. WAMG spontaneous; I. WAMG stimulated; J. Myeloperoxidase activity; K. Lysosyme concentration; L. Lysosyme activity.

Figure 2. Indices of innate immune response after infection with three strains of Lagovirus europaeus GI.1 (RHDV)

Analysis of spontaneous and stimulus WAMG (Figure 2H-I) showed changes depending on the strains applied. In regards to this analysis, only WAMG spontaneous showed increased during Wika strains infection $(1.3$-fold, $\mathrm{p}<0.05)$. Moreover, all three analyzed strains has have elevated parameters of WAMG stimulated (Wika 1.4-fold, $\mathrm{p} \leq 0.0001$; V411 1.4-fold, $\mathrm{p}<0.05$; 1092V 1.1-fold, $\mathrm{p}<0.05$ ) (Figure 2I). Similarly, the activity of MPO (Figure 2J) has been increased at all analyzed strains (Wika 1.1-fold, $\mathrm{p}<0.05$; V411 1.2-fold, $\mathrm{p}<0.05 ; 1092 \mathrm{~V} 1.2$-fold, $\mathrm{p}<0.05$ ). The analysis did not show any changes in the parameter of LZM concentration (Figure $2 \mathrm{~K}$ ); however, LZM activity has been elevated only during V411 antigen infection $(2.4$-fold, $\mathrm{p}<0.05)$ (Figure 2L).

\section{Changes in the adaptive immune response to Lagovirus europaeus Gl.1 (RHDV) infection}

In order to assess changes in the adaptive immune response, individual subpopulations of lymphocytes were analysed on the basis of $\mathrm{CD}$ receptor $\left(\mathrm{CD}^{+}, \mathrm{CD} 4^{+}, \mathrm{CD} 8^{+}, \mathrm{CD} 25^{+}, \mathrm{CD} 19^{+}\right)$ using flow cytometry (Figure 3A-E).

In terms of the adaptive immune response, Ig (ZST units) and IgG immunoglobulins were determined in the serum of infected rabbits (Figure $3 \mathrm{~F}-\mathrm{G}$ ). 

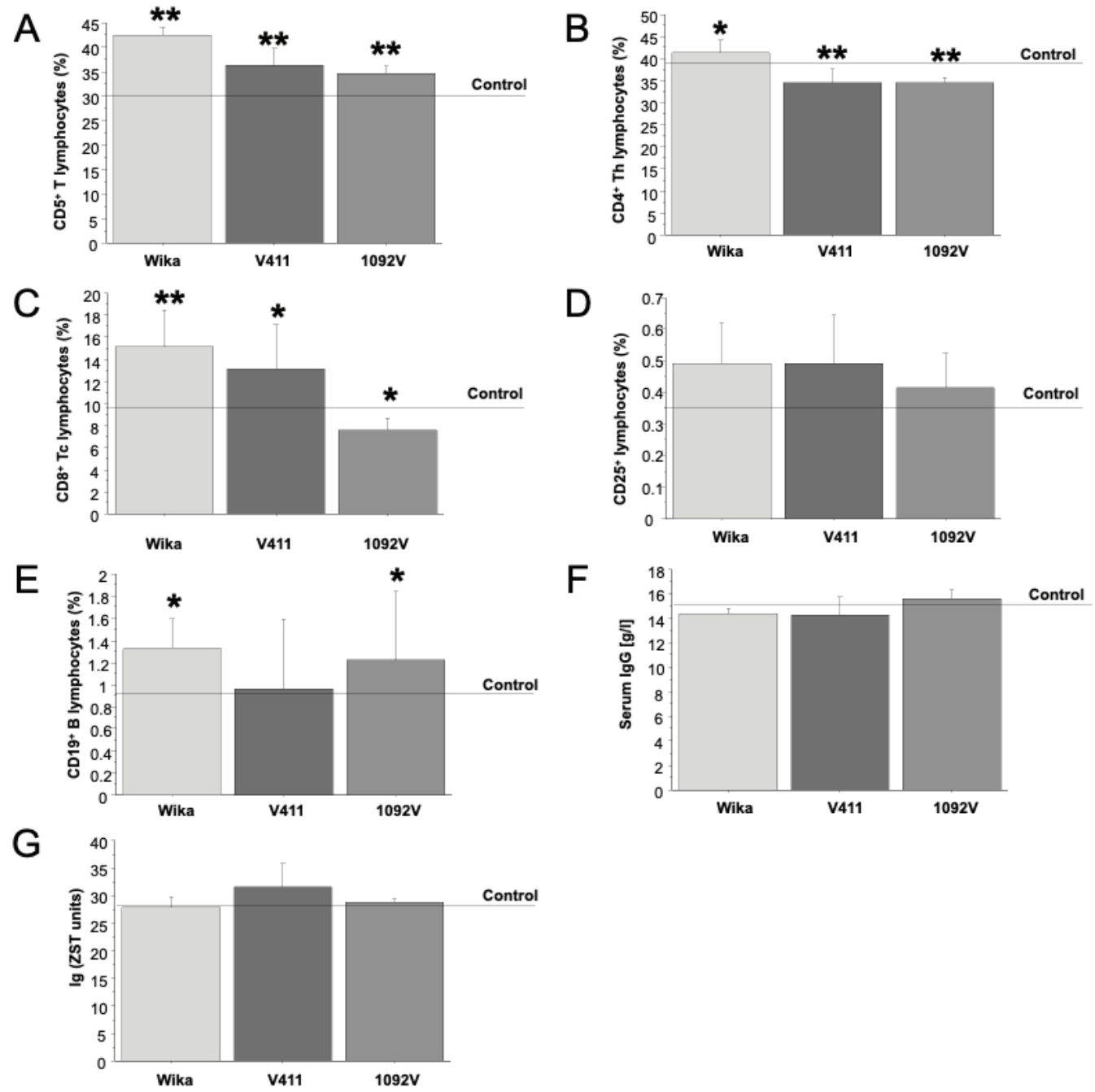

$* \mathrm{p}<0.05 ; * * \mathrm{p} \leq 0.0001$. A. CD5 ${ }^{+}$T lymphocytes; B. CD4 ${ }^{+}$Th lymphocytes; C. CD8 ${ }^{+}$Tc lymphocytes; D. CD25 lymphocytes; E. CD19+ B lymphocytes; F. Serum IgG; G. Ig (ZST units).

Figure 3. Indices of adaptive immune response after infection with three strains of Lagovirus europaeus GI.1 (RHDV)

Analysis of $\mathrm{CD}^{+} \mathrm{T}$ cells (Figure 3A) showed elevated overall frequency for all three antigens (Wika 1.4-fold, $\mathrm{p} \leq 0.0001$; V411 1.2-fold, $\mathrm{p} \leq 0.0001$; 1092V 1.1-fold, $\mathrm{p} \leq 0.0001$ ). Analysis of $\mathrm{CD}^{+}$Th cells (Figure 3B) showed elevated frequency only for Wika antigen (1.1-fold, $\mathrm{p}<$ 0.05). After infection with V411 and $1092 \mathrm{~V}$ strains, observed a $12 \%$ reduction of $\mathrm{CD}^{+} \mathrm{Th}$ cells abundance $(\mathrm{p} \leq 0.0001)$. Frequency of $\mathrm{CD}^{+} \mathrm{Tc}$ cells (Figure $3 \mathrm{C}$ ) has been increased after infection 
with Wika (1.6-fold, $\mathrm{p} \leq 0.0001)$ and V411 (1.4-fold, $\mathrm{p}<0.05)$ antigens. For 1092V strain, observed a $20 \%$ reduction of $\mathrm{CD} 8^{+} \mathrm{Tc}$ cells count $(\mathrm{p}<0.05)$. The amount of CD25+ $\mathrm{T}$ cells (Figure $\left.3 \mathrm{D}\right) \mathrm{did}$ not show any changes after infection with three strains of RHDV. The analysis showed an elevated amount of B cells (Figure 3E) after Wika (1.5-fold, $\mathrm{p}<0.05)$ and 1092V (1.4-fold, $\mathrm{p}<0.05)$ strains infection. Infection with V411 antigen did not change the numbers of B cells in comparison to controls group $(\mathrm{p}=0.7)$. Lack of changes in the total amount of serum Ig (ZST units) and IgG (Figure $3 \mathrm{~F}-\mathrm{G}$ ) has been observed in all analyzed RHDV strains.

\section{Clinical Signs of RHD and mortality}

All rabbits infected with three analyzed strains RHDV died with symptoms of RHD within 24-48 h of the infections (Figure 4).

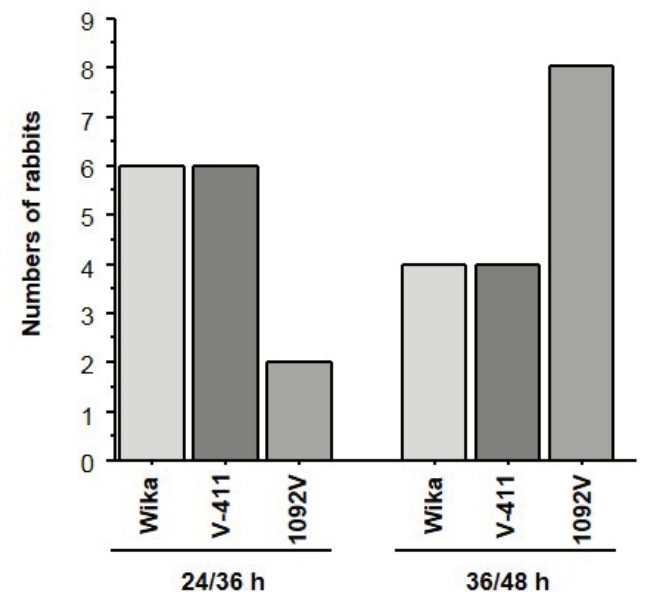

Figure 4. Mortality in the course of Lagovirus europaeus GI.1 (RHDV) infection

A few hours before death, rabbits showed listlesness and acute respiratory distress, characteristic for RHD. There was a marked difference in the survival rates and survival times depending on the strain of RHDV infection. The highest mortality for Wika and V411 strain has been noticed between 24/36 hours post infection with the number of 6 rabbits death. In contrast, mortality after $1092 \mathrm{~V}$ antigen infection has been the highest between $36 / 48$ hours post infection ( 8 rabbits death). Serological studies performer with ELISA test before the commencement of the experiment did not reveal presence of anti-RHDV antibodies in blood serum of rabbits in infected and control groups. Zoo-hygienic conditions in which the animals remained during the experiments, as regards the temperature, humidity and lighting, corresponded to standards applicable to rabbits in Poland. 


\section{Discussion}

The response of the host immune system to the viral pathogen requires the activation of mechanisms related to the recognition of the virus with appropriate precision and in due time, followed by mechanisms of virus elimination (Chaplin, 2010; Chapel et al., 2009; Iwasaki, Pillai, 2014). An immense role is played by factors affecting the extent and severity of the infection pathogen-dependent factors including dose, virulence, and the route of entry, and host-dependent factors: integrity of immune mechanisms, efficiency of host immune system, previous exposure to the pathogen, and the occurrence of co-infections (Chapel et al., 2009). RHDV belongs to the group of viruses inducing acute infections associated with massive and rapid virus expansion, so the host immune response (both cellular and humoral) must be sufficient to block the penetration of viruses into cells and eliminate infected cells in order to limit the spread of the virus in the body.

The study showed that the infection of rabbits with three different RHDV strains triggered changes in both innate and adaptive immune response. In the innate immune response changes were recorded in nine (adherence of capacity, absorption capacity of PMN cells, \% of absorbing cells, NBT reduction test-stimulated, index of stimulation, WAMG spontaneous and stimulated, MPO activity and LZM activity) out of twelve examined indices. All the above mentioned indices (except for LZM activity, whose activity was determined in serum) reflected the biological activity of PMN cells (neutrophils) (Berridge, Herst, Tan, 2005; Niedźwiedzka-Rystwej, Deptuła, 2008; Odobasic, Kitching, Holdsworth, 2016; Wang, Arase, 2014), which is an outstanding indication of phagocytosis activation during this infection. LZM activity has been elevated only during V411 antigen infection. A recent study by Hrynkiewicz, Bębnowska, Niedźwiedzka-Rystwej (2020) suggest that LZM and MPO may serve as a prognostic marker of the state of the immune system of rabbits infected with RHDV. Which may indicate antiviral effect and stimulating phagocytic activity of neutrophils and monocyte proliferation (Ibrahim, Matsuzaki, Aoki, 2001). This confirms the results of tests other RHDV strains (Hukowska-Szematowicz, 2013; HukowskaSzematowicz, Deptuła, 2008; Hukowska-Szematowicz, Deptuła, 2011; Niedźwiedzka-Rystwej, 2013; Niedźwiedzka-Rystwej, Deptuła, 2010; Tokarz-Deptuła, 2009; Trzeciak-Ryczek, TokarzDeptuła, Deptuła, 2016; Trzeciak-Ryczek, Tokarz-Deptuła, Deptuła, 2017). The data presented in previous studies were collected in a dynamic system (several time points), while in this study they were presented in a static system. It should also be emphasized that PMN cells are not only first-line defence cells in this viral infections; they also modulate elements of adaptive immune response and can regulate $\mathrm{T}$ and $\mathrm{B}$ cells (Borregaard, 2010; Liew, Kubes, 2019). It should be remembered that there is a complex interaction between neutrophils and adaptive immunity to provide a smooth immune response to pathogens (Kołaczkowska, Kubes, 2013; Liew, Kubes, 2019; Mantovani et al., 2011). Moreover, it should be emphasized that out of three tested strains (1092V, V411, Wika) with very similar virulence, the youngest Wika strain from 1996 turned out to be the most immunogenic, which was manifested by the increase of innate immunity indices. The two phylogenetically oldest strains - Hungarian 1092V from 1988 and Austrian V411 from 1989 caused similar immune responses.

RHDV-induced adaptive immune response was observed in four (percent of $\mathrm{CD}^{+} \mathrm{T}$ lymphocytes, percent of CD4 $4^{+}$Th lymphocytes, percent of $\mathrm{CD}^{+} \mathrm{Tc}$ lymphocytes, percent of $\mathrm{CD} 19^{+} \mathrm{B}$ lymphocytes) out of the seven examined indices (Figure 3A-C, E). It should be noted that only the Wika strain infection caused an increase in lymphocytes $\mathrm{CD}^{+} \mathrm{T}, \mathrm{CD} 4^{+} \mathrm{Th}, \mathrm{CD} 8^{+} \mathrm{Tc}$, and $\mathrm{CD} 19^{+}$ 
B. This fact may indicate, high immunogenicity of the strain and efficient antiviral defense of the host, but not sufficient for the elimination of the virus and survival of animals. $\mathrm{CD}^{+} \mathrm{T}, \mathrm{CD}^{+}$ Th and $\mathrm{CD} 8^{+} \mathrm{Tc}$ lymphocytes play a particularly important antiviral role by balancing the fight against the pathogen and the risk of chronic inflammation (Chaplin, 2010; Li et al., 2020; Sissons, Oldstone, 1980; Withmire, 2011). The biological role of $\mathrm{CD}^{+} \mathrm{T}$ lymphocytes is to regulate the intensity of intracellular signaling induced by the antigen receptor, which is crucial for maintaining lymphocyte homeostasis (Chaplin, 2010, Chapel et al., 2009). This research confirms the increase in $\mathrm{CD}^{+} \mathrm{T}$ lymphocytes during infection with each of the three tested strains. In turn, $\mathrm{CD} 4^{+} \mathrm{Th}$ lymphocytes promote the production of virus-specific antibodies by activating T-dependent $\mathrm{B}$ cells (Whitmire, 2011). CD8 ${ }^{+}$Tc cells are cytotoxic and may kill the virus-infected cells, which may reduce the disease by eliminating the infectious agent (Sissons, Oldstone, 1980). It should be emphasized that in viral infections $\mathrm{CD}^{+} \mathrm{T}$ cells sustain antiviral $\mathrm{CD} 8^{+} \mathrm{T}$ cell responses during infections, which is confirmed by the results after Wika infection (Whitmire, 2011). In the absence of $\mathrm{CD}^{+} \mathrm{T}$ cells, there is minimal or no expression of $\mathrm{CD}^{+} \mathrm{T}$ cells and deficiencies in cellular immunity (Whitmire, 2011), which is confirmed by research after infection with $1092 \mathrm{~V}$ strain. It should be noted that after infection with Wika and $1092 \mathrm{~V}$ strain, an increase in CD19 ${ }^{+}$ B lymphocytes was observed, which, as indicated by research, are the driving force of immunity in response to pathogens, during both primary and repeat infections (Lam, Baumgarth, 2019; Szikora et al., 2017). Infection of any of the tested strains did not affect the change of CD25+ lymphocytes, whose biological role is to inhibit proliferation of effector lymphocytes and their secretion of proinflammatory cytokines (Lewkowicz, Lewkowicz, Tchórzewki, 2005). There were no changes in IgG and Ig (ZST units), whose role is to neutralize the virus, which prevents its binding to target cell receptors (Chapel et al., 2009). The above test results are partly consistent with earlier findings after infection with other RHDV strains (Hukowska-Szematowicz, 2013; Hukowska-Szematowicz, Deptuła, 2008; Hukowska-Szematowicz, Deptuła, 2011; NiedźwiedzkaRystwej, 2013; Niedźwiedzka-Rystwej, Deptuła, 2010; Tokarz-Deptuła, 2009; Trzeciak-Ryczek, Tokarz-Deptuła, Deptuła, 2016; Trzeciak-Ryczek, Tokarz-Deptuła, Deptuła, 2017) however, as already highlighted, they were presented in the dynamic system. The mortality rate was $100 \%$, and was similarity to the mortality reported for other RHDV strains (Fitzner, Niedbalski, 2017; Hukowska-Szematowicz, 2013, Niedźwiedzka-Rystwej, 2013; Niedźwiedzka-Rystwej, Deptuła, 2010; Tokarz-Deptuła, 2009).

\section{Conclusion}

Infection of rabbits with three different strains of Lagovirus europaeus GI.1 (RHDV) was manifested by changes in innate and adaptive immune response. The innate immunity indices and previous studies carried in Poland indicate a large role of PMN cells and their products as very important components in immune response in the corse of RHDV infection. However, the changes in adaptive immunity rates give new insights into the role of $\mathrm{T}$ lymphocytes and their subpopulations in this infection, with particular emphasis on $\mathrm{CD} 4^{+} \mathrm{Th}$ and $\mathrm{CD} 8^{+} \mathrm{Tc}$ lymphocytes. At the same time, they suggest that in this infection PMN cells may modulate the elements of adaptive immunity, which constitutes complex interaction ensuring fluent immune response to this pathogen. Of all the strains studied, the youngest evolutionary Wika strain from 1996 turned out to be the most immunogenic, followed by V411 and 1092V. 


\section{Acknowledgement}

I would like to thank Agata Wszołek, PhD (Institute of Biology, University of Szczecin) for help in creating the figure 1 (created with BioRende.com).

\section{References}

Afanasyev, W.I., Kolot, L.I. (1971). Izmienienije peroksydazy i cytochromoksydazy w krowi karpow Cyprinus carpio L. pri krasnuchie. Woprosy Ichtiologii, 11, 940-943.

Annon (1987). Information and training materials of the Laboratory Animals Section, General Assembly of the Agriculture Engineers and Technicians. In: Materiaty informacyjno-szkoleniowe Sekcji ds. Zwierząt Laboratoryjnych ZG Stowarzyszenia Inżynierów I Techników Rolnictwa (pp. 26-77). Warszawa, Poland.

Annon (2006). Regulation of the Minister of Agriculture and Rurl Development of 10 March 2006 on detailed conditions for maintenance of laboratory animals in experimental units, breeding units and suppliers (Polish Journal of Law of 2006. No. 50, item 368).

Berridge, M.V., Herst, P.M., Tan, A.S. (2005). Tetrazolium dyes as tools in cell biology: New insights into their cellular reduction. Biotechnology Annual Review, 11, 127-152.

Borregaard, N. (2010). Neutrophils from marrow to microbes. Immunity Review, 33, 657-670. DOI: 10.1016/j.immuni.2010.11.011.

Capucci, L., Fallacara, F., Grazioli, S., Lavazza, A., Pacciarini, L.M., Brocchi, E. (1998). A further step in the evolution of rabbit hemorrhagic disease virus: the appearance of the first consistent antigenic variant. Virus Research, 58, 115-126. DOI: 10.1016/S01168-1702(98)00106-3.

Chapel, H., Haeney, M., Mishab, S., Snowden, N. (2009). Immunologia kliniczna. G. Senatorski (ed.). Lublin: Wydawnictwo Czelej.

Chaplin, D. (2010). Overview of the Immune Response. Journal Allergy Clinical Immunology, 125, S3-23. DOI: 10.1016/j.jaci.2009.12.980.

Deptuła, W. (1991). Phagocytic activity of neutrophiles (PMN cells) in peripheral blood of bovine infected with (Bovid herpesvirus1-BHV1). Polskie Archiwum Weterynarii, 31, 153-165.

Deptuła, W., Kostrzewa, A., Stosik, M., Tokarz-Deptuła, B., Wiktorowicz, K. (1998). Subpopulations of peripheral blood lymphocytes in rabbits. Nowiny Lekarskie, 67, 377-381.

Esteves, P.J., Abrantes, J., Baldauf, H.M., Ben Mohamed, L., Chen, Y., Neil, Ch., Gonzalez-Gallego, J., Giacani, L., Hu, J., Kaplan, G., Keppler, O.T., Knight, K.L., Kong, X.P., Lanning, D.K., Le Pendu J., Lemos, de Matos A., Liu, J.M., Lope, A.M., Lu, S., Lukehart, S., Manabe, Y.C., Neves, F., McFadden, G., Pan, R., Peng, X.M., Sousa-Pereira, P., Pinheiro, A., Rahman, M., Ruvoen-Clouet, N., Subbian, S., Tunon, M.J., van der Loo, W., Vaine, M., Via, L.E., Wang, S., Mage, R. (2018). The wide utility of rabbits as model of human disease. Experimental and Molecular Medicine, 50, 1-10. DOI: 10.1038/s12276-018-0094.

Fitzner, A., Niedbalski, W. (2017). Różnorodność wirusa RHD-znaczenie epidemiologiczne, diagnostyczne i immunologiczne. Medycyna Weterynaryjna, 73, 811-818. DOI: 10.21521/mw.5815.

Grządzielska, E.B. (1976). Phagocytosis capacity test in neutrophil granulocytes using the NBT test. Doctoral dissertation. Kraków: Academy of Medical.

Hankiewicz, J., Świerczek, E. (1975) Comparative determination of lysozyme plate diffusion method and by nephelometry. Przeglad Lekarski, 32, 376.

Holmes, E.C., Grenfell, B.T. (2009). Discovering the phylodynamics of RNA viruses. (2009). PLoS Computional Biology, 5, e1000505. DOI:10.1371/journal.pcbi.1000505. 
Hrynkiewicz, R., Bębnowska, D., Niedzwiedzka-Rystwej, P. (2020). Myeloperoxidase an lysozymes as pivotal hallmark of immunity status in rabbits. Animals, 10, 1581. DOI: 10.3390/ani10091581.

Huang, Do Hai-Bo. (1991). Vaccination against and immune response viral haemorrhagic disease of rabbits: a review of research in the People's Republic of China. Revue Scientifique et Technique (International Office of Epizootics), 10, 481-498.

Hukowska, B. (2000). The dynamics of the absorption capacity of polymorphonuclear (PMN) cells in the experimental infection rabbits with various doses of French-strain-2 of VHD (viral haemorrhagic disease) virus. Master Dissertation, University of Szczecin, Szczecin, Poland.

Hukowska-Szematowicz, B. (2013). Genetic and immunological characteristics of European strains of RHD (rabbit haemorrhagic disease) virus. Polish Journal of Environmental Studies, 2, 1-114, 2013.

Hukowska-Szematowicz, B., Deptuła, W. (2008). Peripheral blood lymphocytes in rabbits infected with Czech strains, CAMPV-562 and CAMPV-558 of RHD virus. Central European Journal of Immunology, 33, 8-13.

Hukowska-Szematowicz, B., Deptuła, W. (2011). Non-specific immunity in rabbits experimentally infected with Czech strains of the Rabbit haemorrhagic disease virus. Central European Journal of Immunology, 36, 153-159.

Ibrahim, H. R., Matsuzaki, T., Aoki, T. (2001). Genetic evidence that antibacterial activity of lysozyme is independent of its catalytic function. FEBS Letter, 506, 27-32.

Iwasaki, A., Pillai P. S. (2014). Innate immunity to influenza virus infection. Nature Review Immunology, 14, 315-328. DOI: 10.1038/nri3665.

Kolaczkowska, E., Kubes, P. (2013). Neutrophil recruitment and function in health and inflammation. Nature Reviews Immunology, 13, 159-175.

Lam, J. H., Baumgarth, N. (2019). The multifaceted B cel response to influenza virus. Journal Immunology, 15, 351-359. DOI: 10.4049/jimmunol.1801208.

Le Gall-Recule, G., Zwingelstein, F. (2011). Detection of a new variant of rabbit haemorrhagic disease virus in France. Veterinary Research, 168, 137-138. DOI: 10.1136/vr.d697.

Le Pendu, J., Abrantes, J., Bertagnoli, S., Guitton, J.S., Le Gall-Recule, G., Lopes, A.M., Marchandeau, S., Alda, F., Almeira, T., Celio, A.P., Barcena, J., Kurmakina, G., Blanco, E., Calvete, C., Cavadini, P., Cooke, B., Dalton, K., Delibes, Mateos, M., Deptuła, W., Eden, J. S., Wang, F., Ferreira, C.C., Ferreira, P., Foronda, P., Goncalves, D., Gavier-Widen, D. Hall, R., Hukowska-Szematowicz, B., Kerr, P., Kovaliski, J., Lavazza, A., Mahar, J., Malogolovkin, A., Marques, R.M., Marques, S., Martin-Alonso, A., Monterroso, P., Moreno, S., Mutze, G., Neimanis, A., Niedźwiedzka-Rystwej, P., Peacock, D., Parra, F., Rocchi, M., Rouco, C., Ruvoen-Clouet, N., Silva, E., Silverion, D., Strive, T., Thompson, G., Tokarz-Deptuła, B., Esteves P. (2017). Proposal for a unified classification system and nomenclature of lagoviruses. Journal of General Virology, 98, 658-1666. DOI: 10.99/jgv.0.000840.

Lechowski, A., Lenarcik, M., Degórski, A., Winnicka, A. (1991). Serum lysozyme activity and nitroblue tetrazolium reduction test in dogs with diabetes mellitis. Journal of Veterinary Medicines Series A, $38,530-533$.

Lewkowicz, P., Lewkowicz, N., Tchórzewski, H. (2005). Limfocyty T regulatorowe CD4+ CD25 ${ }^{+}$: fizjologia i rola tych komórek w modulowaniu odpowiedzi immunologicznej. Postępy Higieny i Medycyny Doświadczalnej, 59, 362-370.

Li, G., Fan, Y., Lai, Y., Li, G., Li, T.H.Z., Zhou, P., Pan, P. Wang, W., Hu, D., Liu, X., Zhang, Q., Wu, J. (2020). Coronavirus infections and immune responses. Journal Medical Virology, 92, 424-432. DOI: 10.1002/jmv.25685.

Liew, P.X., Kubes, P. (2019). The neutrophil's role during health and disease. Physiological Reviews, 99, 1223-1248. DOI: 10.1152/physrev.00012.2018. 
Liu, S.J., Xue, H.P., Pu, B.Q., Quian, N.H. (1984). A new viral disease in rabbits. Animal Husbandry and Veterinary Medicine, 16, 253-255.

Lorente, F., Fontan, G., Garcia, M.C.R., Ojeda, J.A. (1973). A simple and reproducible method to evaluate granulocyte adherence. Journal of Immunological Methods, 19, 47-51.

Mantovani, A., Cassatella, M., Constantini, C., Jaillon, S. (2011). Neutrophils in the activation and regulation of innate and adaptive immunity. Nature Review Immunology, 11, 519-521. DOI: 10.1038/nri3024.

Marques, R.M., Costa-E-Silva, A., Aguas, A.P., Teixeira, L., Ferreira, P.G. (2012). Early inflammatory response of young rabbits attending natural resistance to calicivirus (RHDV) infection. Veterinary Immunology Immunopathology, 150, 181-188. DOI: 10.1016/j.vetimm.2012.09.038.

Mc Ewan, A.D., Eischer, E.W., Seleman, I.E., Penhale, W.I. (1970). A turbidirty test for the estinesica of immunoglobulin levels in neonatal calf serum. Clinica Chemica Acta, 27, 155-163. DOI: 10.1016/00098981(70)90390-6.

Neves, F., Abrantes, J., Almeida, T., Lemos, de Matos, A., Costa, P.P., Esteves, P.J. (2015). Genetic characterization of interleukins (IL-1 $\alpha$, IL-1 $\beta$, IL- 2, IL-4, IL-8, IL-10, IL-12A, IL-12B, IL-15, IL-18) with relevant biological role in lagomorphs. Innate Immunity, 21, 787-801. DOI: 10.1177/1753425915606209.

Niedźwiedza-Rystwej, P., Deptuła, W. (2010). Non-specific immunity in rabbits infected with 10 strain of the rabbit haemorrhagic disease virus with different biological properties. Central European Journal of Biology, 5, 613-632. DOI: 10.247/s11535-010-0049-6.

Niedźwiedzka-Rystwej, P. (2013). Zjawiska immunologiczne u krolików zakażonych wirusem RHD (rabbit haemorrhagic disease). Praca hab. US. Szczecin: Wyd. PPH Zapol.

Niedźwiedzka-Rystwej, P., Deptuła W. (2008). Phagocytosis of polimorfonuclear cells known and unknown facts. Medycyna Weterynaryjna, 64, 749-752.

Odobasic, D., Kitching, A.R., Holdsworth, S.R. (2016). Neutrophil-mediated regulation of innate and adaptive immunity: the role of myeloperoxidase. Journal of Immunology Research, 2349817, 1-11. DOI: $10.1155 / 2016 / 2349817$.

Park, B.H., Fihring S.M., Smithowich E.M. (1968). Infection and nitroblue tetrazolium reduction by neutrophils: a diagnostic aid. Lance, 2, 532-534. DOI: 10.1016/s0140-6736(68)92406-9.

Pinheiro, A., Neves, F., Lemos, de Matos, A., Abrantes, J., van der Loo, W., Mage, R., Esteves, P.J. (2016). An overview of the lagomorphs immune system and its genetic diversity. Immunogentics, 68, 83-107. DOI: 10.1007/s00251-015-0868-8.

Raman, U., Poland, R.L. (1975). A new microquantitive NBT test. Pediatric Research, 9, 334-336.

Semerjyan, A.B., Sargsyan, M.A., Arzumanyan, H.H., Hakobyan, L.H., Abroyan, L.O., Semerjyan, Z.B., Avetisyan, A.S., Karalova, E.M., Manukyan, D.M., Matevosyan, H.S., Krasniokov, N.F., Karalyan, Z.A. (2019). Immune cell pathology in rabbit hemorrhagic disease. Veterinary World, 12, 1332-1340. DOI: $10.14202 /$ vetworld.2019.1332-1340.

Sissons, J.G.P., Oldstone, M.B.A. (1980). Killing of virus-incected cells by cytotoxic lymphocytes. Journal of Infectious Disese, 142, 114-119.

Szikora, B., Hiripi, L., Bender, B., Kacskovics, I., Ilias, A. (2017). Characterization of the interactions of rabbit neonatal Fc receptor (FcRn) with rabbit and human IgG isotypes. PLoS One, 12, e 0185662. DOI: 10.1371 journal.pone.0185662.

Szmigielski, S. (1972). The analysis of up and down regulated granulocythes. Postdoctoral thesis. Warszawa: Wojskowy Instytut Medycyny Lotniczej.

Teixeira, L., Marques, R.M., Águas, A.P., Ferreira, P.G. (2012). Regulatory T cells are decreased in acute RHDV lethal infection of adult rabbits. Veterinary Immunology Immunopathology, 148, 343-347. DOI: 10.1016/j.vetimm.2012.05.006. 
Tokarz-Deptuła, B. (2009). Immunity phenomena in rabbits infected with the RHD virus (Rabbit Haemorrhagic Disease). Polish Journal of Environmental Studies, 7, 1-81.

Trzeciak-Ryczek, A., Tokarz-Deptuła, B., Deptuła, W. (2016). Expression of IL-1 $\beta$, IL-2, IL-10, TNF- $\beta$ and GM-CSF in peripheral blood leukocytes of rabbits experimentally infected with rabbit haemorrhagic disease virus. Veterinary Microbiology, 186, 71-81. DOI: 10.1016/j.vetmic.2016.02.021.

Trzeciak-Ryczek, A., Tokarz-Deptuła, B., Deptuła, W. (2017). Expression of IL-1Ra, IL-6, IL-8, IL-18, TNF- $\alpha$ and IFN- $\gamma$ genes in peripheral blood leukocytes of rabbits infected with RHDV (Rabbit Haemorrhagic Disease Virus). Developmental \& Comparative Immunology, 76, 310-315. DOI: 10.1016/j. dci.2017.07.005.

Wang, J., Arase, H. (2014). Regulation of immune responses by neutrophils. Annals of New York Academy of Science, 1317, 66-81. DOI: 10.1111/nyas.12445.

Whitmire, J.K. (2011). Induction and function of virus-specific CD4 ${ }^{+} \mathrm{T}$ cell responses. Virology, 411, 216228. DOI: 10.1016/j.virol.2010.12.015.

Zawistowski, S. (1976). Histological technique, introduction to histology and histology. Warszawa: PZWL.

Zeman, K. (1995). Methods of isolation and assessment of neutrophil granulocytes function. Immunologia Polska, 15, 157-162.

Cite as: Hukowska-Szematowicz, B. (2020). Changes in innate and adaptive immune response to Lagovirus europaeus GI.1 (Rabbit Haemorrhagic Disease Virus -RHDV) infection. Acta Biologica, 27, 77-91. DOI: 10.18276/ab.2020.27-08. 